International Conference on Literature, Humanities, Social Sciences and Education (LHSSE-2018)

Kyoto (Japan) April 19-20, 2018

Paper ID: H0418454

\title{
Self-Management Community: A Case Study of Procedures for Association to Solve the Living-Land Problem in Puechudom Subdistrict, Pathum Thani Province, Thailand
}

\author{
Darunsak Tatiyalapa ${ }^{1}$, Ruetai Sumniengsanoh ${ }^{2}$ and Chaded Khotcharit ${ }^{3}$
}

1 a lecturer of Social Science for Local Development Program, 2 a lecturer of English for International Communication Program and 3 an independent researcher, a former lecturer of Thai Language for Communicative Innovation, Valaya Alongkorn Rajabhat University under the Royal Patronage,

Pathum Thani, Thailand

\begin{abstract}
The current article is a part of the research study entitled "Living and Harvesting Land Management Model Building in Puechudom Subdistrict, Lamlukka District, Pathumthani Province, Thailand. The article aims to 1) study about procedures of an association to solve the living-land problem in Puechudom Subdistrict, Lamlukka District, Pathum Thani Province as well as 2) convey and publicize the academic knowledge crossculturally. The information was collected and analyzed using four methods; 1) reviewing relevant literature, 2) on-site observation, 3) in-depth interview and 4) a community forum. Findings were found as follows: Almost of all community members in Puechudom Subdistrict have no title to land, and consequently have hired both paddy land and living land. Unfortunately the community members were pressured to move out since their land had been sold by the landlord. Without their own living land, a number of community member have to hire some land from the community temple. According to the problem having happened all over the area of Puechudom Subdistrict, the community has been gathering to solve such a problem since 1989. Initially, solving-problem procedures were processed in form of trial and error. Fortunately the community leaders have helped push their member into share-and-learn session and stepped forward to the problem-solving stage. Such an initial gathering expressed its community strength. After that, they started to empower their own community by connecting with various helpful networks and organizations with the aim of being offered knowledge and activities for helping solve the inadequate-living-land problem. Eventually, their strength can be proved by founding "a cooperative limited".
\end{abstract}

Keywords: Self-management community, association, living-land problem, Thailand

\section{Introduction}

Even though the globalization trend in the current society implicitly requires us to rely on the central authorities, there is a community who initially developed themselves using self-reliance management to solve their own problem. Despite reducing central reliance, its management becomes reputation as well as has been contributed by various organizations. Moreover, the way they gathered and empowered community member to help solve problem focuses on sustainability and is parallel to their context. Due to the problem solving concept, it was supported by Puang-Ngam (2010) that solving any problems sustainably, community's context and local wisdom should be determined and involved. Moreover, the land allocation has been the chronicle problem in various areas around Thailand including Puechudom community, until now. This is because a few land tenants who are also capitalist own a large number of land, on the other hand, a number of community members who mainly are farmer have no their own land. Due to the problem, Kusantia (2014) concluded that the government has tried to allocate land using various methods, for examples, providing land's document of right, allowing cheap rate of land's hire-purchase including long-run instalment. Such a situation mentioned is the context of Puechudom. 
Besides the problem mentioned, its geography is so appropriate for agriculture that paddy cultivation being completed twice a year. Almost of all farmers hire paddy land from landlord, however some of them have been terminated the hire-purchase contract of land and traded land with high price. Even though farmers need their rented land, they absolutely have no purchasing power to buy it. This concern brought about the association among those who have faced with the problem. Due to the study by Tatiyalapha and Khotcharit (2017), they reported that in 1989 the community leader started founding "Puechudom Co-Operative of Living-land and Harvesting Land Service, Limited" in order to relieve the problem using self-management procedures.

\section{Article's components}

\subsection{Objectives}

- To study about procedures of association to solve living-land problem in Puechudom Subdistrict, Lamlukka District, Pathum Thani Province

- To convey and publicize the academic knowledge cross-culturally

\subsection{Expected Outcomes}

- Obtaining knowledge about procedures of association to solve living-land problem in Puechudom Subdistrict, Lamlukka District, Pathum Thani Province Thailand

- Obtaining a model of association to solve living-land problem which is probably a beneficial application to those who may need to employ it depending on their context

- Being able to convey and publicize academic knowledge cross-culturally

\subsection{Research Methods}

The information was collected and analyzed using four methods; firstly, reviewing relevant literature, secondly, on-site observation, thirdly, in-depth interview and the last method was a community forum.

\subsection{Analytic Results}

- Procedures of association to solve living-land problem of the community in Puechudom Subdistrict, Lamlukka District, Pathum Thani, Thailand:

The problem of inadequate living-land became more severely since a part of community member's contract of hire-purchase of land was terminated. Consequently, there was no land left both for cultivating and living. Despite getting in trouble, they shared the understanding to the same obstacle and, finally, gathered the member for initiating self-management. After community association was established, its member tried to solve the problem with various processes in form of trial and error depending on any pressured situation. Every time all members gathered, they reflected their problems, emotions and suggestions. This made them gradually learn how strong the association was. Besides learning about the power of association, the skills of community leaders were also developed. Having been empowered, community member and leader started exploring opportunities to associate with potential networks within Puechudom community and outside the area including government sectors and civil society. The community expects to be supported and recommended all kinds of efficient working-procedures which can, hopefully, lead to successful solutions for self-managing harvesting and living land problems. 


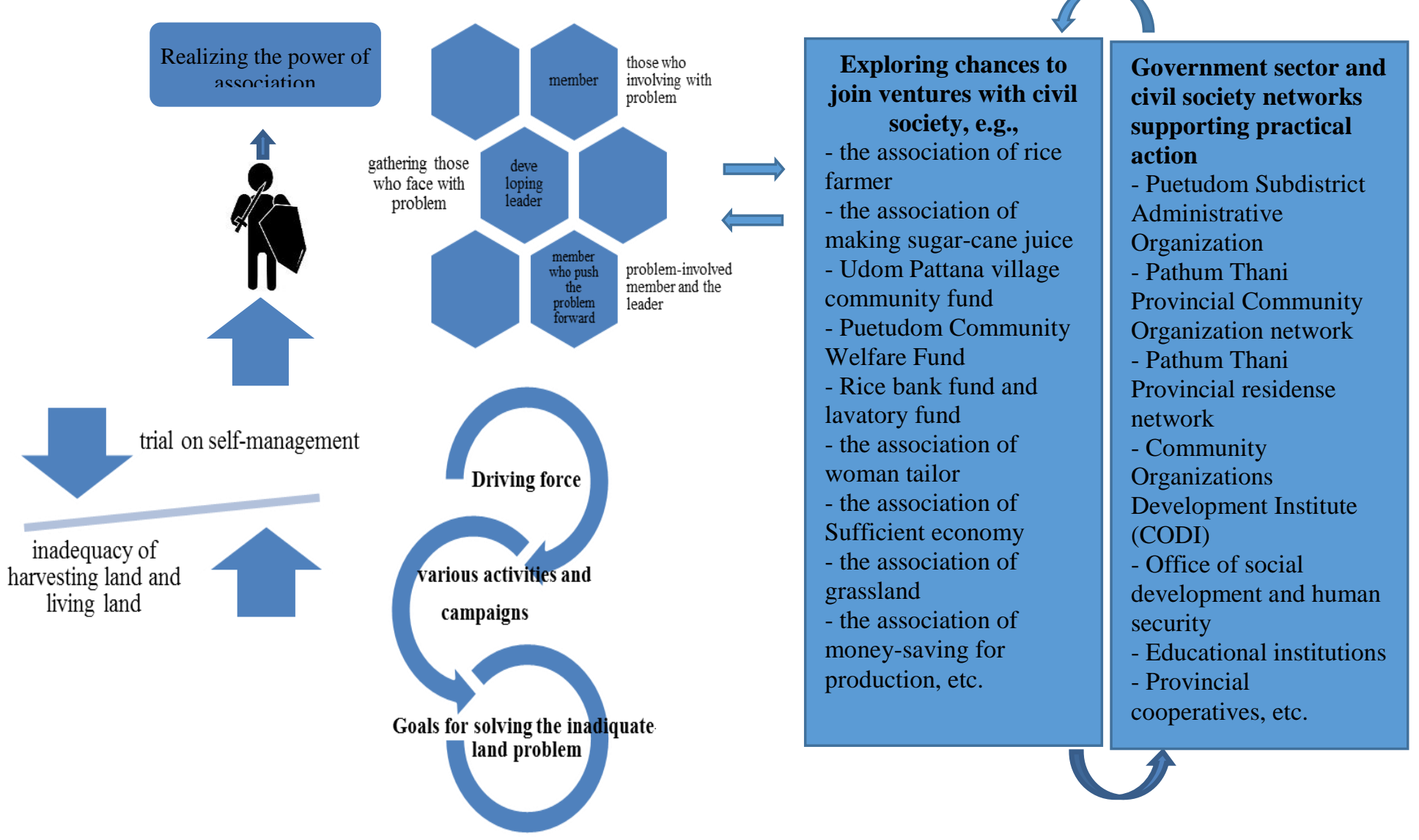

Fig. 1: showing the exploration of the cooperation and gathering working group to push forward the land problem.

- Working plan based on nine steps of self-management procedures:

Having gathered constructively, Puechudom community has forcefully and systematically solved the problems. In addition, various networks in forms of the government sector and civil society have supported the community's operation. To operate any activities or campaigns effectively, community's operations are depended on nine steps of self-management procedures. 


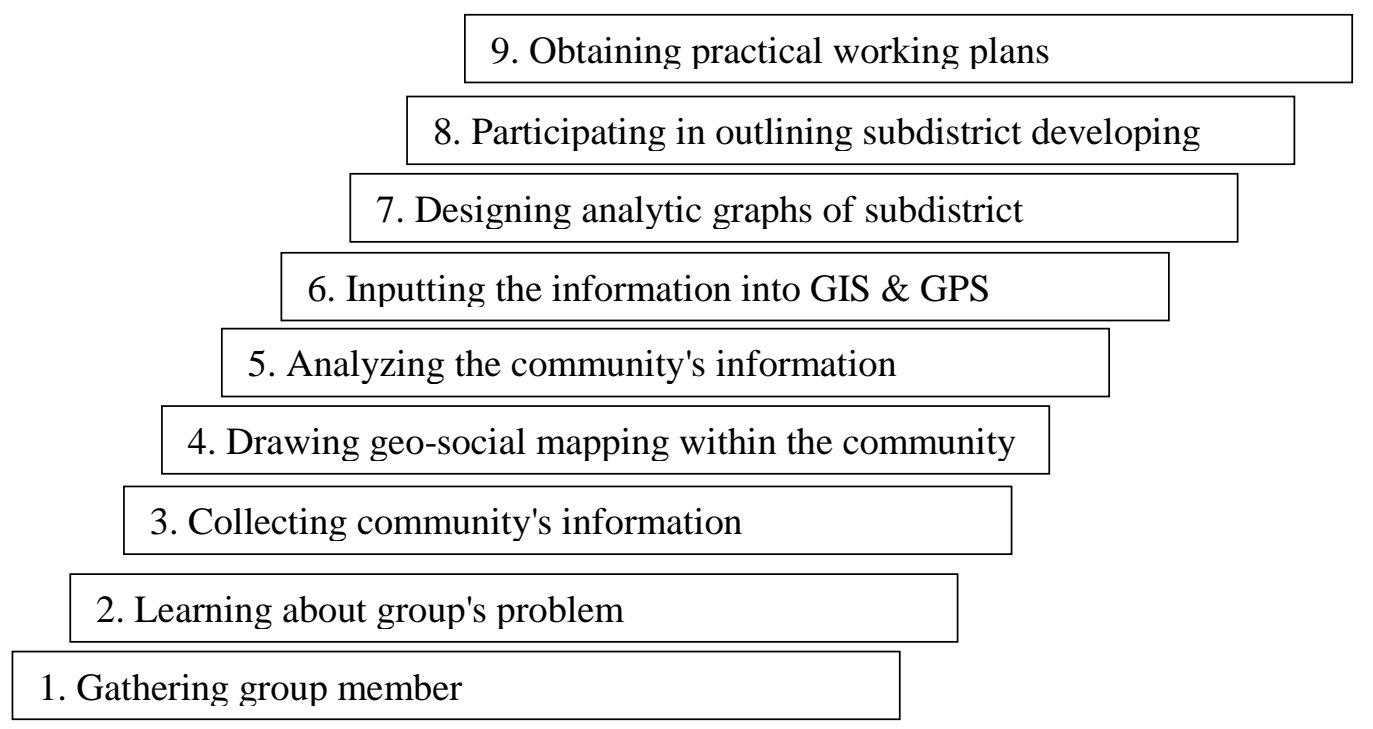

Fig. 2: Working plan based on nine steps of self-management procedures.

\subsection{Conclusion}

Puechudom, one of the small communities in Thailand, and its community members have expressed their strong effort in form of self- management to solve the community's main problem. Besides self-management, the association is another powerful operation for solving problem. However, they are always willing to learn and adapt any knowledge, support and cooperation from different networks. A successful result of learning and exploring problem's solution is "Puechudom Co-operative of Living Land and Harvesting Land Service, Limited". Such evidence can be proved that Puechudom community really realizes the power of association and genuinely uses self-reliance management for their own living.

\section{Acknowledgements}

To achieve the current article completely, the following networks always come to our mind: Valaya Alongkorn Rajabhat University (VRU.), Research and Development Institute VRU., Community Organizations Development Institute (CODI) and Puetudom Co-operative of Living and Harvesting Land Service, Limited are those who always facilitate us all kind of information during the research period. We would like to appreciate all of their support here.

Besides the organizations mentioned, many community members are willing to participate with various research activities. This is their kindness to us.

\section{References}

[1] Puang-ngam, K., (2010). Self-management of Community and Local Organizations. Bangkok: Bopit Printing.

[2] Project of Puetudom Residense and Arable Land. (n.d.). Mimeographed. Pathum Thani: The committee of Puetudom Co-operative of Residense and Arable Land.

[3] Khotcharit, C. (2009). Thai Economic System under World economy. Articles of Thainess: Society Economics and Culture. Pathum Thani: Valaya Alongkorn Rajabhat University.

[4] Tatiyalapha. D. \& Khotcharit, C. (2017). Residense and Arable Land Management: Case Study of Puetudom Subdistrict, Lumlukka District, Pathum Thani Province. Journal of Research and Development Valaya Alongkorn Rajabhat University under the Royal Patronage. 12(2): 299-311.

[5] Kusantia, A. (2007). Land Loss of Farmer. [Online]. Available from: http://www. landactionthai.org. Accessed. 2018 March 19. 